effects and benefits of hand treatment must be care fully designed to determine whether the procedure is cost-effective and when it is required to prevent infection, if this is to be our aim.

\section{REFERENCES}

1. Ehrenkranz NJ. Bland soap handwash or hand antisepsis? The pressing need for clarity. Infect Control Hosp Epidemiol. 1992;13:299-301.

2. Dubbert PM, Dolce J, Richter W, Miller M, Chapman SW. Increasing ICU staff handwashing: effects of education and group feedback. Infect Control Hosp Epidemiol. 1990;11:191-193.

3. Simmons B, Bryant J, Nieman K, Spencer L, Arheart K. The role of handwashing in prevention of endemic intensive care unit infections. Infect Control Hosp Epidemiol. 1990;11:589-594.

4. Albert RK, Condie F. Handwashing patterns in medical intensive care units. New Engl J Med. 1981;304:1465-1466.

5. Quraishi ZA, McGucken M, Blais FX. Duration of handwashing in Intensive Care Units. Am/Infect Control. 1984;12:83-87.

6. Graham M. Frequency and duration of handwashing in an intensive care unit. Am IInfect Control. 1990;18:77-81.

7. Larson E. A causal link between hand washing and risk of infection? Examination of the evidence. Infect Control Hosp Epidemiol. 1988;9:28-36.

8. Casewell M, Phillips I. Hands as a route of transmission for Klebsiella species. BMJ 1977;2:1315-1317.
9. Massanari RM, Hierholzer WJ Jr. A crossover comparison of antiseptic soaps on nosocomial infection rates in intensive care units. Am J Infect Control. 1984;12:247-248. Abstract.

10. Black RE, Dykes AC, Anderson K, et al. Handwashing to prevent diarrhea in day-care centers. Am J Epidemiol. 1981;113:445-451.

11. Kahn MV. Interruption of shigellosis by handwashing. Trans $R$ Soc Trop Med Hyg. 1982;76:164-168.

12. Hedrick E. Infectious waste management: will science prevail? Infect Control Hosp Epidemiol. 1988;9:488-490.

13. MRC War Memorandum No. 6. The prevention of hospital infection of wounds. London, England: His Majesty's Stationery Office; 1942.

14. Doebbeling BN, Stanley GL, Sheetz T, et al. Comparative efficacy of alternative handwashing agents in reducing nosocomial infections in intensive care units. New Engl J Med. 1992;327:88-93.

15. Meers PD, Yeo GA. Shedding of bacteria and skin squames after handwashing. J Hyg Camb. 1978;81:99-105.

16. Ojajarvi J, Makela P, Rantasalo I. Failure of hand disinfection with frequent hand washing: a need for prolonged field studies. $J$ Hyg Camb. 1977;79:107-119.

17. Kaplan LM, McGucken M. Increasing handwashing compliance with more accessible sinks. Infect Control. 1986;7:408-410.

18. Mayer JA, Dubbert PM, Miller M, Burkett PA, Chapman SW. Increasing handwashing in an intensive care unit. Infect Control. $1986 ; 7: 259-262$.

\title{
Department of Transportation Delays Rules on Medical Waste
}

\section{by Gina Pugliese, RN, MS Medical News Editor}

In response to petitions requesting a withdrawal of medical waste provisions in a final rule that amended the Hazardous Materials Regulation, the Department of Transportation (DOT) extended the compliance date to January 1 , 1994, to allow the opportunity for public comment. ${ }^{1}$

The amended Hazardous Materials Regulations would have expanded the infectious substance (formerly called etiologic agent) category of regulated hazardous materials to include medical waste. The rule would have adopted the expired medical waste tracking act definitions for medical waste, significantly increasing the amount of medical waste in this country.

Concern has been voiced to DOT in numerous petitions and comment letters that there is no evidence of the need to further regulate medical waste. Of particular concern is the potential overlap and inconsistency with other federal agencies that already have regulations applying to infectious substances and etiologic agents, including the Occupational Safety and Health Administration (OSHA), Centers for Disease Control and Prevention (CDC), the United States Postal Service (USPS), the Animal and Plant Health Inspection Service
(APHIS), and the Food and Drug Administration (FDA).

In an Advance Notice of Proposed Rulemaking, the DOT acknowledged the need for additional public input. A public hearing was held on March 17, 1993, and DOT requested written comments regarding the definitions of etiologic agents, exceptions for biologic products and diagnostic specimens, adoption of universal precautions, and labeling and packaging requirements.

\section{REF ER EN CE}

1. Department of Transporation. Infectious Substances: Notice of Public Hearing and Advanced Notice of Proposed Rulemaking. Federal Register. March 3, 1993:12207-13. 